\title{
Chilling requirement of four peach cultivars estimated by changes in flower bud weights ${ }^{1}$
}

\author{
Chaiane Govea Milech ${ }^{2}$, Maximiliano Dini ${ }^{3}$, Rodrigo Cezar Franzon ${ }^{4}$, Maria do Carmo Bassols Raseira $*$ (D)
}

10.1590/0034-737X202269010004

\begin{abstract}
The adaptation of temperate fruit crops is a challenge being increased by the global warming. Chilling requirement is a key factor for adaptation. The objective of this study was to estimate the chilling requirement of peach cultivars BRS Bonão, Esmeralda, Granada and Eragil, using the Tabuenca test. Chilling accumulation was computed using four different chilling hour $\left(\mathrm{d}+7.2^{\circ} \mathrm{C}\right.$ and $\left.\mathrm{d}+11^{\circ} \mathrm{C}\right)$ models; and chill units using the Low Chill model and the Taiwan model. The fresh bud weight and bud water contents were also evaluated. The Tabuenca test (based on differences in bud's dry weight) showed a fairly good efficiency for estimating the end of dormancy in peach. However, under mild winter conditions, it is better to use fresh bud weights. Either one of three chilling accumulation computation models (temperature $\mathrm{d}+7.2^{\circ} \mathrm{C}, \mathrm{d}+11^{\circ} \mathrm{C}$, or Taiwan model) is suitable to classify comparatively different cultivars, but none is accurate enough to conclude on the adaptation of a given cultivar to a specific site. Using hours of temperatures $\mathrm{d}+11{ }^{\circ} \mathrm{C}$ : 'BRS Bonão' needed around 180 hours for dormancy release; 'Esmeralda' around 250 hours; 'Granada' between 300 and 400 hours, and 'Eragil' more than 500 hours.
\end{abstract}

Key words: Prunus persica (L.) Batsch; Tabuenca test; mild winter; dormancy; low chill cultivars.

\section{INTRODUCTION}

Climatic patterns have undergone changes on a global scale, greatly affecting meteorological, environmental, biological, economic, and social processes (IPCC, 2013).

Perennial species of temperate climate are vulnerable to changes in temperature, since their development is largely dependent on this factor (Walthall et al., 2012). Bud dormancy has been studied for years, aiming to understand the aspects involved in dormancy induction, maintenance and suppression (Hauagge \& Cummins, 1991).

Peach (Prunus persica L. Batsch) is one of the temperate climate fruit species that has experienced the greatest expansion and is now found in subtropical and high altitude tropical regions. For this reason, and in view of the global warming, the development of low chilling cultivars is one of the priorities of most breeding programs.
Cold accumulation is the main responsible factor for dormancy release of deciduous fruit species. Thus, whenever these species are grown in regions with insufficient chilling accumulation, they do not adapt well and show symptoms as deficient leafing; strong apical dominance with consequent inhibition of lateral shoots; development of long terminal branches and uneven flowering which drastically affect production (Marodin $e t$ al., 1992). Although the dormancy can be overcome using chemical substances, vegetative growth, yield and fruit quality are generally lower than those from adapted cultivars (Donadio, 2007). However, under field conditions it is practically impossible to estimate the exact chilling accumulation required for dormancy release of a specific cultivar, since other factors such as solar radiation, temperature fluctuations, among others, may not be controlled (Dennis, 2003).

\footnotetext{
Submitted on October $15^{\text {th }}, 2020$ and accepted on June $6^{\text {th }}, 2021$.

${ }^{1}$ This work is part of the first author's doctoral thesis.

${ }^{2}$ Universidade Federal de Pelotas, Programa de Pós-graduação em Agronomia (Fruticultura de Clima Temperado), Pelotas, Rio Grande do Sul, Brazil. chaiane.gm@hotmail.com

${ }^{3}$ Instituto Nacional de Investigación Agropecuaria, Programa Nacional de Investigación en Producción Frutícola, Estación Experimental INIA Las Brujas, Rincón del Colorado, Canelones, Uruguay. mdini@inia.org,uy

${ }^{4}$ Embrapa Clima Temperado, Pelotas, Rio Grande do Sul, Brazil. rodrigo.franzon@embrapa.br; maria.bassols@embrapa.br

*Corresponding author: maria.bassols@embrapa.br
} 
Much research has been carried out for estimating chilling requirement of stone fruit cultivars. Different mathematical models have been used, differing as to the relative efficiency of the various temperature ranges, among which the Utah model (Richardson et al., 1974), Dynamic model (Fishman et al., 1987), Taiwan model (Ou \& Chen, 2000), and Low Chill model (Gilreath \& Buchanan, 1981). There are also protocols called phenological models, which are generally used in combination with these models. Therefore, in addition to temperature data, phenological models also use plant phenology data over the years. Some researchers base this calculation on the beginning of leafing dates (10\% bud burst), others base on the full flowering dates (50\% opened flowers), and also others estimate chilling requirement by comparing to known cultivars.
Another approach used by several researchers are the biological methods (Herter et al., 2001; Carvalho et al., 2010; Malagi et al., 2015). There are also variations among biological methods, such as the use of a whole plant or just a part of it, as isolated bud cuttings (Pouget, 1963), detached branches (Weinberger, 1950), and/or buds as in the Tabuenca protocol (Tabuenca, 1964). The Tabuenca test is an old biological method, still widely used, as it allows to establish when the chilling requirement has been satisfied. It has already been successfully applied in apricot (Tabuenca, 1964; Legave et al., 2010; Andreini et al., 2014), peach and pear (Tabuenca, 1964), plum (Tabuenca, 1967) and apple (Malagi et al., 2015).

The objective of the study was to estimate the chilling requirement of peach cultivars BRS Bonão, Esmeralda, Granada and Eragil, using the Tabuenca test.
2015
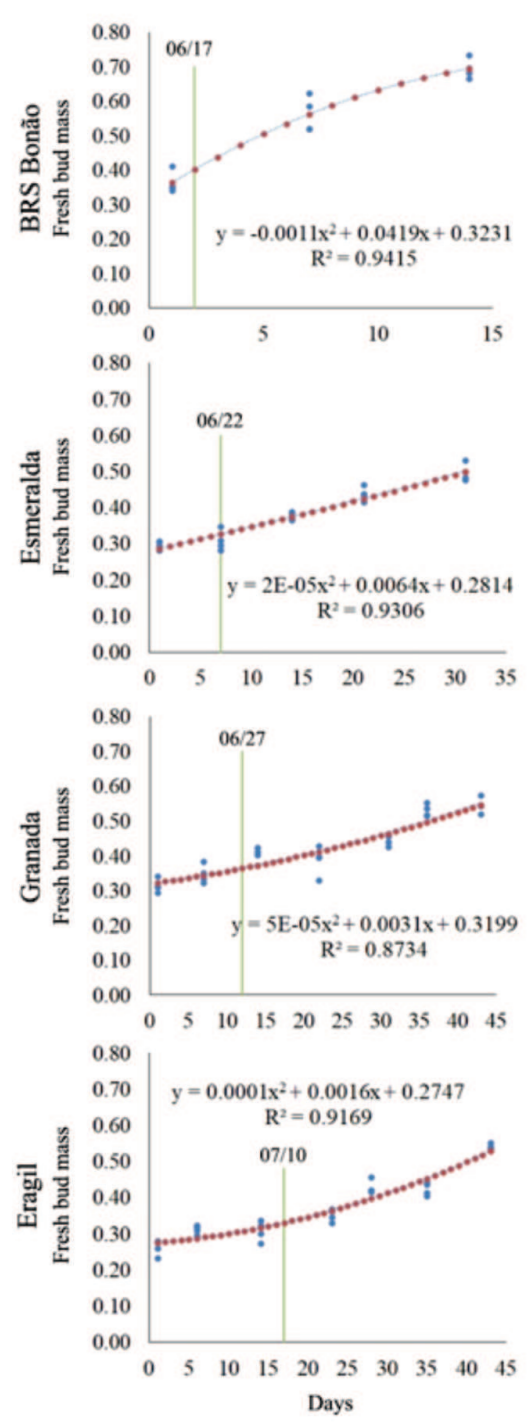

2016
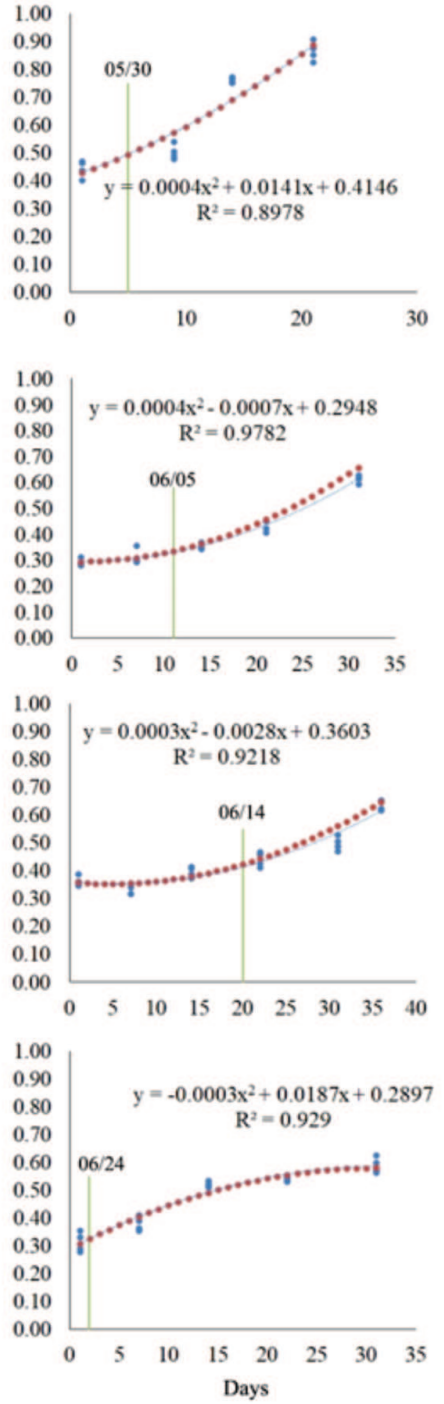

2017
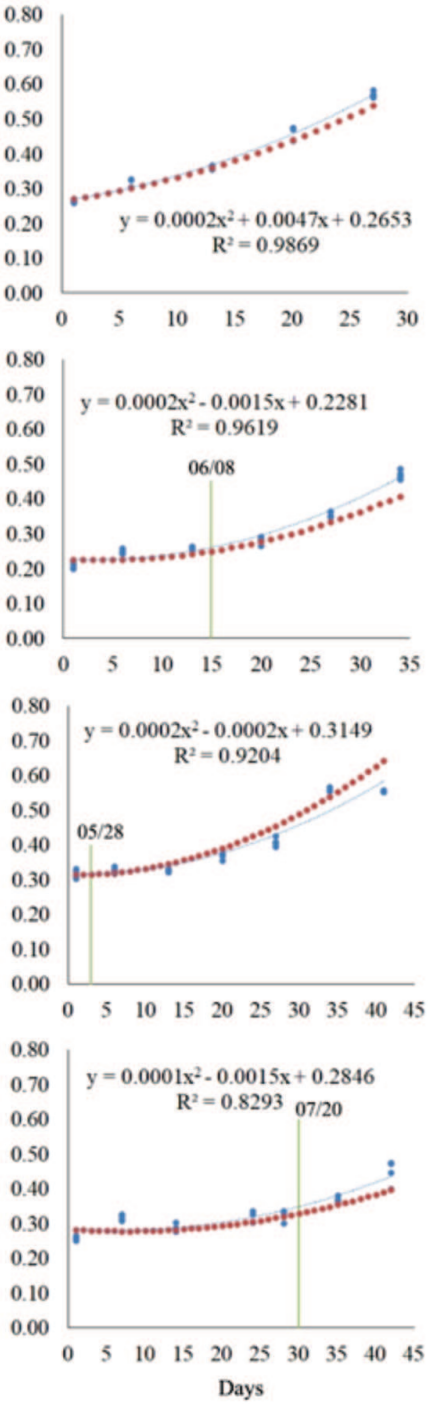

- Actual sampling dates • Estimated chilling accumulation every other day based on the regression $\mid$ Endodormancy release

Figure 1: Regression curves for four peach cultivars in 2015, 2016, 2017 seasons, considering the fresh mass of flower buds. The date of dormancy break corresponds to the first significant increase of the bud weight, using the MSD test $(p \leq 0.05)$. 


\section{MATERIAL AND METHODS}

The experiment was conducted in commercial orchards located in Pelotas, RS, for three consecutive years (2015, 2016 and 2017). Adult plants of four peach cultivars, BRS Bonão, Esmeralda, Granada and Eragil, were used. The first three cultivars were developed by Embrapa Temperate Agriculture, and 'Eragil' is a cultivar selected by a grower in Santa Catarina state.

The plants of cvs. BRS Bonão and Esmeralda were located in Colonia Cristal, the $5^{\text {th }}$ District of Pelotas (31 $34^{\circ} 45.001^{\prime \prime S}$; 52²8’42.895"W), those of 'Granada' in Colonia São Manuel, the $8^{\text {th }}$ District of Pelotas $\left(31^{\circ} 29\right.$ '26.020"S; 52 32'8.268"W) and the ones of 'Eragil', in Colonia Santa Eulália, the $5^{\text {th }}$ District of Pelotas (31³3’30.917"S; 52³2' 22.549"W). These cultivars were chosen for their different chilling requirements. 'BRS
Bonão' has the lowest chilling requirement (less than 200 hours $\left.\leq 7.2^{\circ} \mathrm{C}\right)$, 'Esmeralda' and 'Granada', medium (250 and 400 hours $\leq 7.2^{\circ} \mathrm{C}$, respectively), and 'Eragil', high chilling requirement (over 500 hours d" $7.2^{\circ} \mathrm{C}$ ) (Franzon \& Raseira, 2014).

The accumulation of chilling hours was calculated using temperatures $\leq 7.2{ }^{\circ} \mathrm{C}$ (Weinberger, 1950) and temperatures $\leq 11^{\circ} \mathrm{C}$ (Chavarria et al., 2000). Chill units (or cold units) were calculated for each collection date using Low Chill (Gilreath \& Buchanan, 1981) and Taiwan (Ou \& Chen, 2000) models. These models were chosen based on previous work in which they seemed to be the most suitable for the Pelotas area (Milech et al. 2018a, 2018b).

At the beginning of the experiment (2015), four uniform plants per cultivar were marked (each plant was a
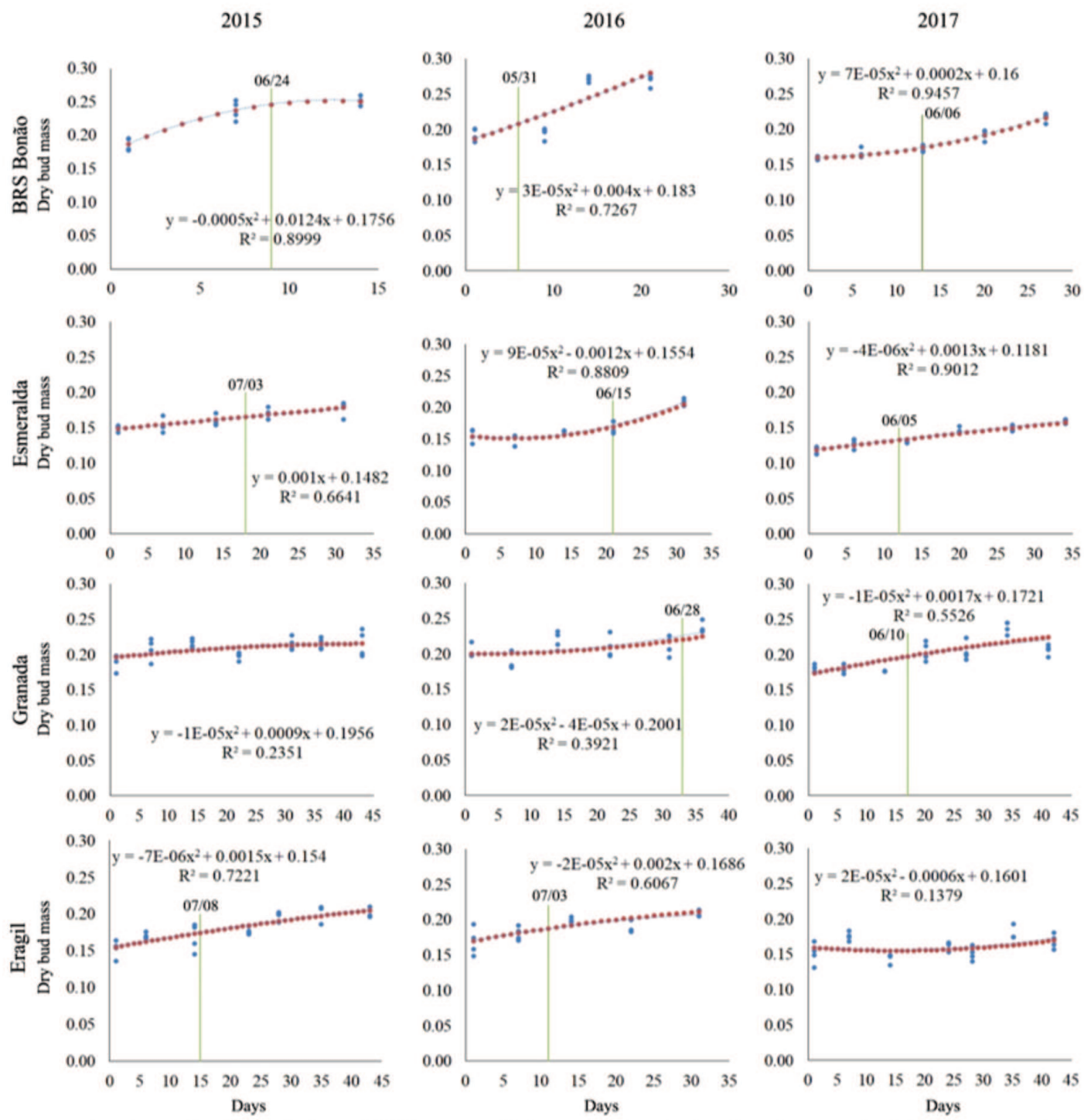

- Actual sampling dates - Estimated chilling accumulation every other day based on the regression Endodormancy release

Figure 2: Regression curves for four peach cultivars in 2015, 2016, 2017 seasons, considering the dry mass of flower buds. The date of dormancy break corresponds to the first significant increase of the bud weight, using the MSD test $(p \leq 0.05)$. 
replication) for the three-year shoot collections. Sampling of five $30 \mathrm{~cm}$ long shoots per plant started near 50 hours of temperature $\leq 7.2{ }^{\circ} \mathrm{C}$ had been accumulated, in each collection site. These collections continued weekly, during the months of May, June, July and August, until beginning of blooming (anthesis of $10 \%$ flower buds) occurred in the orchard. Shoots were randomly collected in different orientation of the plant at the medium height of the canopy. So, in each collection date, 20 one-year old shoots per cultivar were cut and immediately taken to the laboratory and placed in vials containing $150 \mathrm{~mL}$ of $3 \%$ aqueous sucrose solution. They were kept for seven days in a germination chamber (Fitotron ${ }^{\circledR}$ ), at a temperature of $21 \pm 1$ ${ }^{\circ} \mathrm{C}$ and a photoperiod of 12 hours. The sucrose solution was changed every two days.

The temperature data on the field were recorded from May $1^{\text {st }}$ until the end of the winter by data loggers (Novus, Logchart II version 2.62), installed near each orchard.

Immediately after branch collection, 20 flower buds were removed from each sample, which constituted the experimental unit, totalizing 80 buds per cultivar. The bracts and pedicel were removed from the buds, and then each sample was weighed on an analytical scale to obtain their fresh mass. After, the buds were taken to drying oven at \pm $70{ }^{\circ} \mathrm{C}$, until constant mass was obtained $(0.05 \%$ variation, \pm 3 days), and then, they were weighed again to obtain their dry mass. The collections were carried out until a significant increase in the mass was observed, which it was defined as the date of the end of endodormancy.

Originally, the Tabuenca test (Tabuenca, 1964) is based on the changes in dry mass of the flower buds. However, in the present study, the bud fresh masses were also measured.

The experimental design was a completely randomized, with four replications of 20 buds per plot. First, the regression equations were calculated for each cultivar, considering the average masses obtained on each collection date. Subsequently, the daily average of the bud mass was calculated using regressions, and these were compared two by two by the minimum significant difference (MSD) to estimate the first significant increase of the bud mass.

For this established date, calculations were made for $\mathrm{CH}$ accumulation $\leq 7.2^{\circ} \mathrm{C}$ (Weinberger, 1950), $\mathrm{CH} \leq 11^{\circ} \mathrm{C}$ (Chavarria et al., 2000), and CU according to Taiwan (Ou \& Chen, 2000), and the Low Chill model (Gilreath \& Buchanan, 1981). Using the averages and standard error, comparisons were made among the chilling requirements of the cultivars (considering the dates obtained by the Tabuenca method and the chilling accumulation by the four models). A comparison was also made among years, within the same model. Additionally, for these established dates, the water content (\%) of the buds was calculated.

\section{RESULTS AND DISCUSSION}

The Tabuenca method, followed by the regression calculations and MSD of the fresh and dry mass of the buds, between two consecutive days, allowed to estimate the date of the dormancy break for each cultivar (Figures 1 and 2). Tabuenca (1964 and 1967) used only the flower bud dry mass, however, his work was carried out in Zaragoza, Spain, where winters are well defined and

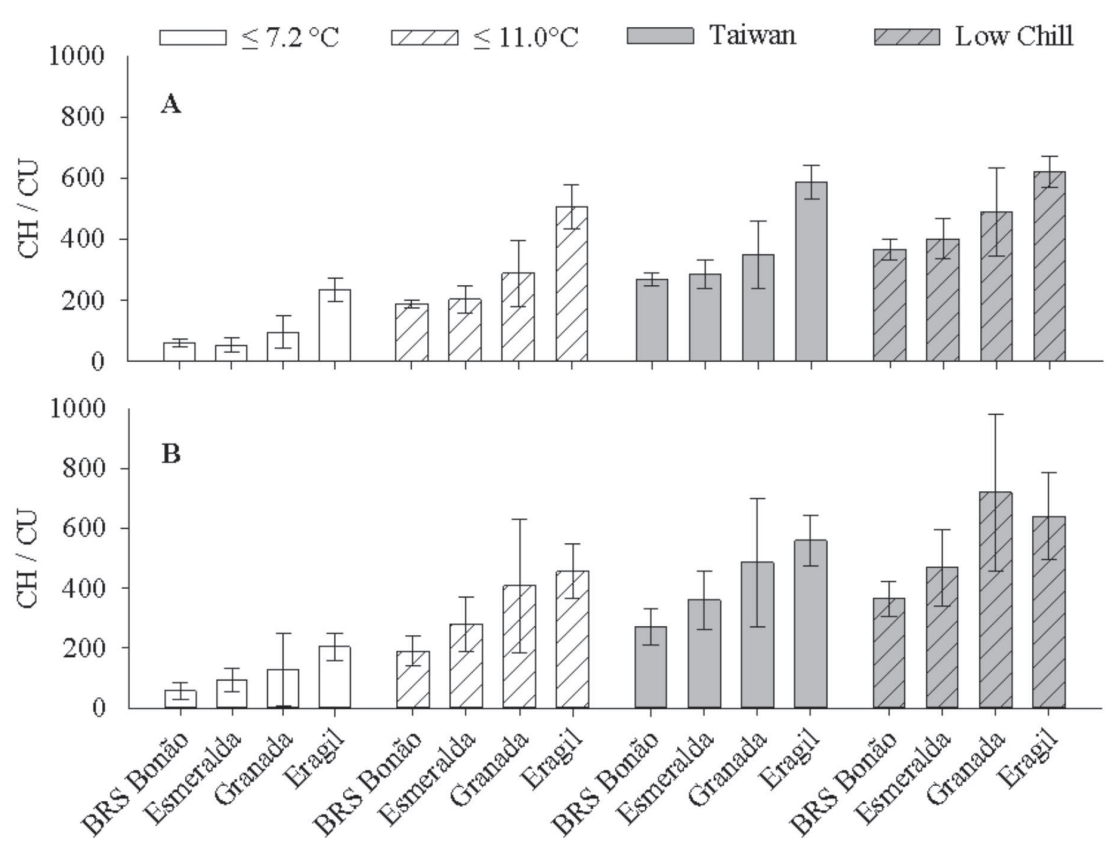

Figure 3: Chilling requirement of four peach cultivars estimated by four models using bud fresh weight (A) or dry bud weight (B). Vertical bars represent the standard deviations of the mean; $\mathrm{CH}=$ Chill hours; $\mathrm{CU}=$ Chill units. 


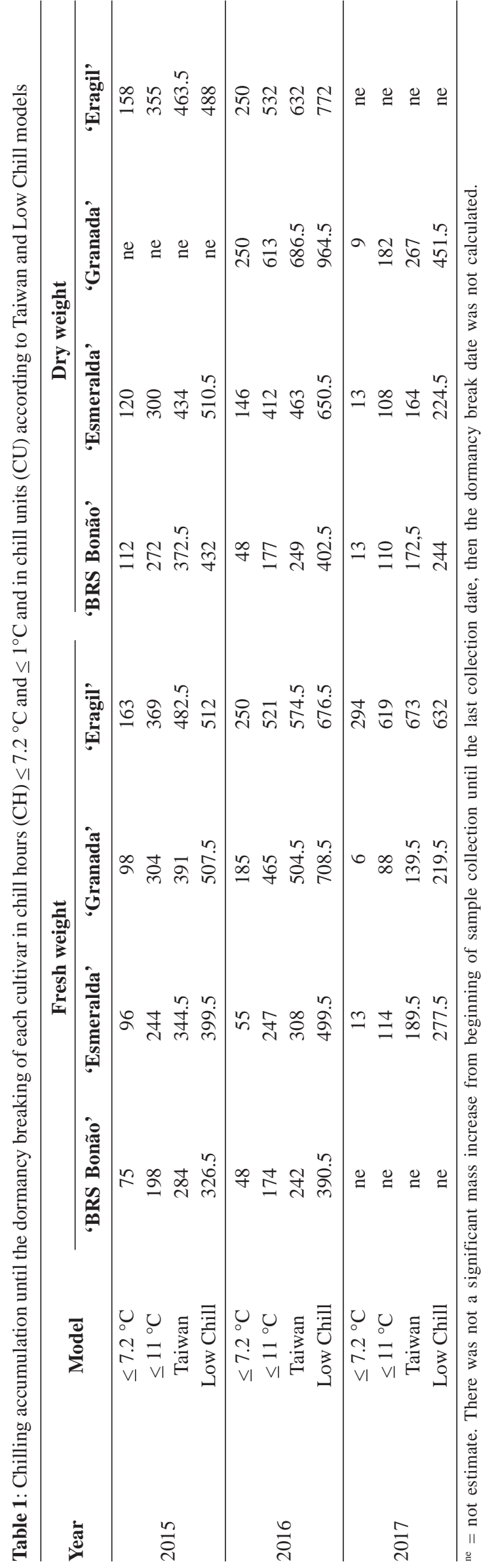

cultivars have high chilling requirement, which is not the case of Southern Brazil. In the present study, the differences among genotypes were better observed when using the flower bud fresh mass. The same comparative order was maintained, regardless of use $\mathrm{CH}$ or $\mathrm{CU}$, except for a slight difference (between 'Granada' and 'Eragil') in the Low Chill model, when using the dry mass (Figure 3).

The comparison among genotypes using means and respective standard deviation (Figure 3), confirmed the classification of 'BRS Bonão' as the one with the lowest chilling requirement but it did not significantly differ from 'Esmeralda' and 'Granada', differing from 'Eragil', which it has the highest need in chilling accumulation among them.

The cultivar BRS Bonão, in the year 2015, had a significant increase of the bud mass, on June 17. On this date, the accumulated chilling hours of temperature d" 7.2 ${ }^{\circ} \mathrm{C}$ and d" $11^{\circ} \mathrm{C}$ were $75 \mathrm{CH}$ and $198 \mathrm{CH}$, respectively. If models of chill units are used, it would correspond to 284 $\mathrm{CU}$ and 326.5 CU for Taiwan and Low Chill models, respectively (Table 1). In 2016, the date of significant increase in fresh flower bud mass occurred on May, 30. This was possibly related to the fact that in the year of 2016, temperatures in May were lower than in 2015 and 2017, and, consequently, the CU accumulation in this period was practically double (Table 2 ).

May temperatures are of great influence, mainly for low chill cultivars, as they can determine if these cultivars will or not go into dormancy. Dormancy entry and depth are strongly correlated with cold winter temperatures (Malagi et al., 2015). On May 30 the chilling accumulations were $48 \mathrm{CH} \leq 7.2{ }^{\circ} \mathrm{C}, 174 \mathrm{CH} \leq 11^{\circ} \mathrm{C}$, and $242 \mathrm{CU}$, by the Taiwan model and $390.5 \mathrm{CU}$ by the Low Chill model. Cold unit accumulation at the beginning of May possibly supplied enough chill and since it was followed by warm temperatures at the end of the same month, the increase in the bud weight was stimulated. These results can be explained by the very low chilling requirement of 'BRS Bonão'.

Low temperatures have a double function on dormancy mechanisms of deciduous fruit trees. They induce the entry and exit of dormancy, in order to allow leafing and flowering development (Putti, 2001). The transition between the endodormancy and ecodormancy phases is not well defined, but it is assumed that this transition may become shorter due to global warming, causing earlier flowering (Aguilera et al., 2014).

In 2017 there was not a significant difference in the 'BRS Bonão' flower bud fresh mass, due to the fact that temperatures remained high in the fall, which probably led this cultivar not going into deep dormancy (Figure 1).

'Esmeralda' had the first significant increase in the flower bud fresh mass on June 22, in 2015 (Figure 1). By 
then, there was an accumulation of $96 \mathrm{CH}\left(\leq 7.2^{\circ} \mathrm{C}\right), 244 \mathrm{CH}$ $\left(<11^{\circ} \mathrm{C}\right)$, and $344 \mathrm{CU}$, by the Taiwan model and $399.5 \mathrm{CU}$ by the Low Chill model (Table 1). In 2016, 'Esmeralda' showed similar dynamics as the previous year, for models of hours below $11{ }^{\circ} \mathrm{C}$ and the Taiwan model, with the significant increase occurred on June 5, with an accumulation of 247 $\mathrm{CH}\left(\leq 11^{\circ} \mathrm{C}\right)$ and $308 \mathrm{CU}$ by the Taiwan model. The difference in dates was probably due to the cold that occurred in May of 2016, and thus necessary chill accumulation for this cultivar occurred earlier (Table 2). In 2017, the significant increase in the bud fresh mass was observed on June 8, with chilling accumulation well below the previous years (Table 1). 'Esmeralda' is considered a medium chilling requirement cultivar, however, in May 2017, temperatures did not drop much (the daily average was between $16^{\circ} \mathrm{C}$ and $17^{\circ} \mathrm{C}$ ). So, it is very likely that the cultivar did not go into endodormancy that year, thus responding to the higher temperatures. Temperate species, when grown in areas of mild climate, such as Southern Brazil, rarely meet their chilling requirements during winter (Hawerroth et al., 2010). Thus, it is believed that over time there will be some level of adaptation of the cultivars to the climate, with increasingly warm temperatures.

Considering the changes in the bud weight of 'Granada', there was not the same trend in the three years of the experiment (Figure 1). According to the literature, 'Granada' is also considered as medium chill cultivar, requiring between 250 and 400 hours of temperature $\leq 7.2^{\circ} \mathrm{C}$. However, as the hourly temperatures and monthly accumulations in the winter months were very variable from one year to the next, it was not possible to estimate conclusively the chilling requirement of this cultivar by any of the models for chill accumulation computation. Analyzing the temperature and chilling accumulation data for the winter months, in the years in which the experiments were carried out $(2015,2016$ and 2017) it was possible to observe large fluctuations in hourly temperatures and a large difference in the onset of cold among the years (Table 2).

The established dates, based on the MSD, both for fresh (Figure 1) and dry mass of buds (Figure 2), were different as well as the chilling accumulation. In 2015, MSD for bud fresh mass of 'Granada' occurred on June 27 which corresponded to $98 \mathrm{CH}\left(\mathrm{d}\right.$ " $\left.7.2{ }^{\circ} \mathrm{C}\right)$ and $304 \mathrm{CH}\left(\mathrm{d}\right.$ " $\left.11{ }^{\circ} \mathrm{C}\right)$, and for the Taiwan and Low Chill models, 391 and 507.5 $\mathrm{CU}$, respectively. Dormancy entry and depth are strongly correlated with cold winter temperatures. The quality and regularity of the cold during dormancy are extremely important for the development of the peach tree (Gonçalves, 2014). In other words, the effects of cold can be assessed in terms of duration (quantitative aspect) and intensity (qualitative aspect). Under warm winter conditions, as Southern Brazil, the three classic phases of dormancy (paradormancy, endodormancy and ecodormancy) are difficult to differentiate, where the endodormancy, if it does occur, is mild and short. The results for ' $G$ ranada' (Table 1) in 2016 were $185 \mathrm{CH}\left(\leq 7.2^{\circ} \mathrm{C}\right), 465 \mathrm{CH}(\leq$ $11^{\circ} \mathrm{C}$ ), 504.5 CU (Taiwan model) and 708.5 CU (Low Chill model), on June 14. As already referred, the regularity with which the cold occurs is of great importance. Temperature fluctuations increase the need for chilling hours to satisfy the plant's requirements (Erez \& Lavee, 1971). It is important that enough chilling occurs during the winter (especially in the beginning) to satisfactorily overcome the dormancy (Champagnat, 1973). When this

Table 2: Comparison of the monthly chill accumulation in May, June and July, in the years of 2015, 2016 and 2017, in one specific site (Colônia São Manuel, Pelotas, and the average mean temperature, the average maximum, and the average minimum temperature, for the same months and years for Pelotas

\begin{tabular}{|c|c|c|c|c|c|c|}
\hline \multirow{2}{*}{ Year } & & \multicolumn{3}{|c|}{ Embrapa Weather Station ${ }^{1}$} & \multicolumn{2}{|c|}{ Colônia São Manuel $^{2}$} \\
\hline & & Average & Maximum & Minimum & $\leq 7.2^{\circ} \mathrm{C}$ & $\leq 11^{\circ} \mathrm{C}$ \\
\hline \multirow{4}{*}{2015} & May & 16.9 & 21.8 & 13.2 & 27 & 95 \\
\hline & June & 14.3 & 19.4 & 9.9 & 71 & 211 \\
\hline & July & 13.9 & 17.9 & 10.7 & 25 & 178 \\
\hline & & & & Total & 123 & 484 \\
\hline \multirow{4}{*}{2016} & May & 13.6 & 17.5 & 10.8 & 67 & 223 \\
\hline & June & 10.6 & 15.3 & 7.5 & 183 & 396 \\
\hline & July & 12.6 & 17.0 & 9.0 & 119 & 273 \\
\hline & & & & Total & 369 & 892 \\
\hline \multirow{4}{*}{2017} & May & 16.7 & 20.7 & 13.4 & 6 & 100 \\
\hline & June & 14.9 & 20.0 & 10.9 & 73 & 226 \\
\hline & July & 15.3 & 21.3 & 10.9 & 115 & 203 \\
\hline & & & & Total & 194 & 529 \\
\hline
\end{tabular}

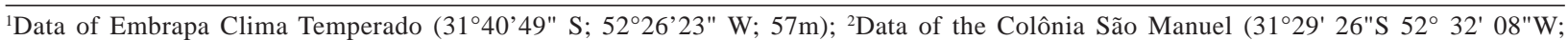
$223 \mathrm{~m})$. 
occurs, the development of the floral primordium is then dependent on the heat accumulation which is also variable depending on the cultivar (Citadin et al., 2001). The year 2017 was a very unusual and hot year, and when the minimum significant difference in the bud fresh mass occurred in 'Granada' (May 28), there was practically none or very little $\mathrm{CH}$ accumulated of temperatures $\leq 7.2{ }^{\circ} \mathrm{C}$ or $\leq$ $11^{\circ} \mathrm{C}$, and also very low CU accumulation (Table 2). Therefore, it is very likely that 'Granada' did not go into dormancy that year (Table 1).

Large temperature fluctuations in winter besides canceling the $\mathrm{CH}$ already accumulated induces the plants to early flowering, causing significant damage to production (Gonçalves, 2014). Moreover, the significant increase of the flower bud mass of some low cultivars and not in others may be an indication of a different heat requirement for blooming.

The results for 'Eragil' were very inconsistent. Observing the 2015 data, a significant increase in bud fresh mass occurred on July 10 , with $163 \mathrm{CH}\left(\leq 7.2^{\circ} \mathrm{C}\right)$, $369 \mathrm{CH}\left(\leq 11^{\circ} \mathrm{C}\right), 482.5 \mathrm{CU}$ for the Taiwan model and 512 CU for the Low Chill model. On the following year (2016), the date was advanced to June 24, and the chilling accumulations were already higher than the previous year, with values of $250 \mathrm{CH}, 521 \mathrm{CH}, 574.5 \mathrm{CU}$ and 676.5 $\mathrm{CU}$, for temperature $\leq 7.2^{\circ} \mathrm{C}, \leq 11^{\circ} \mathrm{C}$, Taiwan and Low Chill models, respectively. In 2017, 'Eragil' had a significant increase in bud fresh weight later than the previous two years (July 20). For this date, $294 \mathrm{CH}(\leq 7.2$ $\left.{ }^{\circ} \mathrm{C}\right), 619 \mathrm{CH}\left(\leq 11^{\circ} \mathrm{C}\right), 673 \mathrm{CU}$ (Taiwan) and $632 \mathrm{CU}$ (Low Chill) were accumulated. The deeper the endodormancy, the greater the amount of $\mathrm{CH}$ needed to overcome it, which implies the crop failure of some cultivars of temperate climate when cultivated in subtropical or tropical environments (Erez, 2000). However, the biggest problem of adaptation of deciduous fruit crops to the region under study refers to the fact that large temperature fluctuations generally occur during the

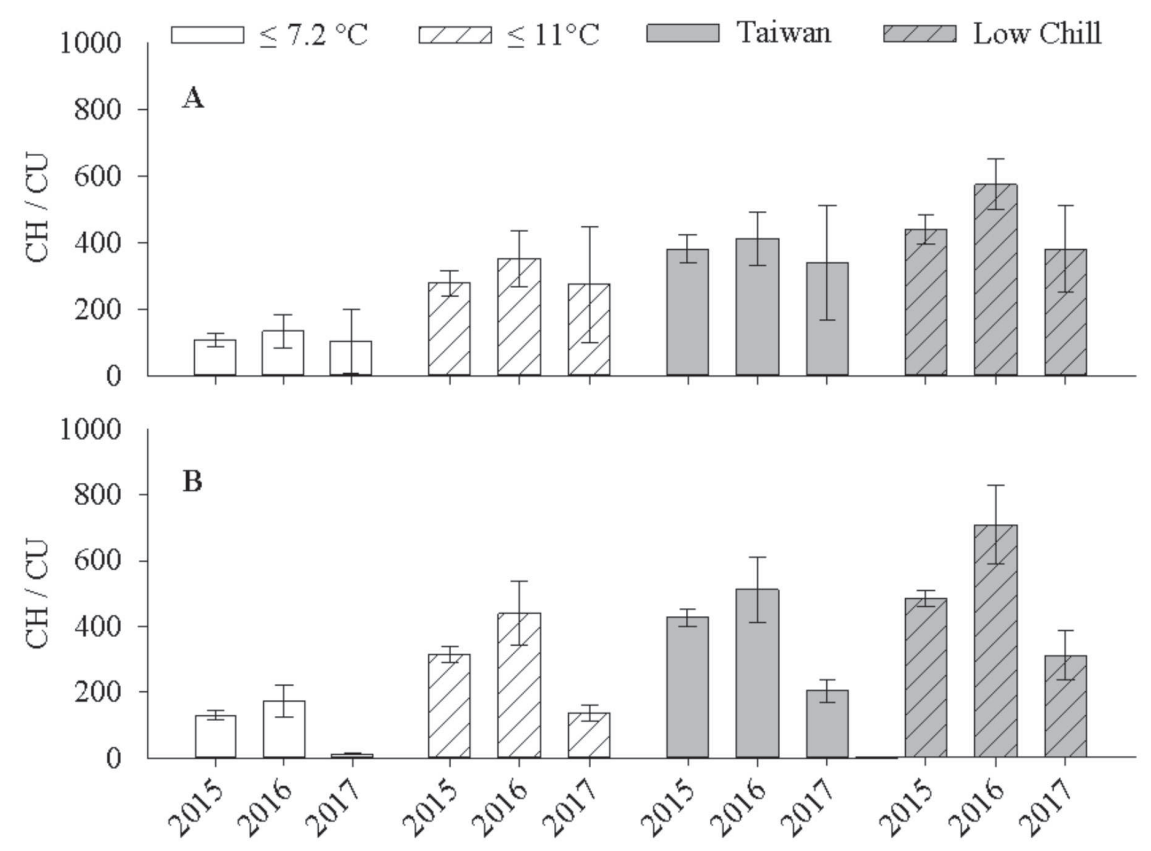

Figure 4: Comparison among years for average chilling accumulation, using four models and bud fresh weight (A) and dry bud weight (B), of four peach cultivars (BRS Bonão, Esmeralda, Granada and Eragil). Vertical bars represent the standard deviation of the mean; $\mathrm{CH}=$ Chilling hours; $\mathrm{CU}=$ Chill units.

Table 3: Water content (\%) in flower buds of four peach cultivars at the estimated date of dormancy release

\begin{tabular}{lllll}
\hline Cultivar & $\mathbf{2 0 1 5}$ & $\mathbf{2 0 1 6}$ & $\mathbf{2 0 1 7}$ & CV (\%) \\
\hline BRS Bonão & $48.31 \mathrm{~B}^{\mathbf{1}}$ & $61.25 \mathrm{~A}$ & ne & 5.54 \\
Esmeralda & $50.1 \mathrm{n}^{\mathrm{ns}}$ & 53.06 & 49.47 & 4.93 \\
Granada & $46.26 \mathrm{~B}$ & $52.57 \mathrm{~A}$ & $45.45 \mathrm{~B}$ & 4.41 \\
Eragil & $45.46 \mathrm{~B}$ & $46.41 \mathrm{~B}$ & $53.32 \mathrm{~A}$ & 4.09 \\
\hline
\end{tabular}

${ }^{1}$ Means followed by the same letters in the line (comparing years) do not differ by the Tukey test at $5 \%$ probability; ns $=$ not significant by the F-test $(p \leq 0.05)$; ${ }^{\text {ne }}=$ not estimate; $\mathrm{CV}=$ coefficient of variation. 
winter season. It is important to point out that it is not uncommon the occurrence of days when temperatures exceed $25^{\circ} \mathrm{C}$, even in coldest winter months.

The chilling requirement estimation for a certain cultivar should be the same over different years if the method and model adopted were sufficiently accurate. The Tabuenca model recommends using the flower bud dry weight, however the results obtained in our study were not consistent. For this reason, we decided to compare the results obtained using the bud fresh mass and their dry mass in the three studied years, in order to verify which is the most reliable for chilling requirement estimation. Observing the data set of four cultivars, for the three studied years, with the exception perhaps of the estimates made by the Low Chill model, there was no statistical difference between the years, considering the bud fresh weights. However, the same was not true for the dry weights (Figure 4). This makes sense considering that among the characteristics that undergo modification when a dormant cell becomes active, the cell turgor is one of the most noticed. And it is strictly linked to the percentage of water in the tissues.

The results for bud water content were stable, with approximately $50 \%$ for all cultivars, on the date of the estimated endodormancy break. The differences, even when statistically significant, were less than $10 \%$ (Table 3 ). The water content was associated with the plant dormancy state, in previous studies, in apple (Malagi et al., 2015; Sachet, 2013), peach (Leite et al., 2006; Bonhomme et al., 1997), and pear trees (Marafon et al., 2011; Simões et al., 2014). The percentage of water in the flower buds probably reveals the end of endodormancy and could be an alternative method for estimating it.

\section{CONCLUSIONS}

Under the conditions of this work we conclude that:

'BRS Bonão' needs around $190 \mathrm{CH}$ of temperature $\leq$ $11^{\circ} \mathrm{C}$ for dormancy breaking; 'Esmeralda' needs close to $250 \mathrm{CH}$; 'Granada' needs between 300 and $400 \mathrm{CH}$; and 'Eragil' needs more than $500 \mathrm{CH}$.

Either one of three models (hours of temperature $\leq 7.2$ ${ }^{\circ} \mathrm{C}$, hours of temperature $\leq 11^{\circ} \mathrm{C}$, or chill units by the Taiwan model) is suitable to classify comparatively different cultivars, but none of them is accurate enough to conclude on the adaptation of a given cultivar to a specific site.

The Tabuenca test has a fairly good efficiency to estimate the end of a dormancy phase in peach.

Under warm winter conditions for the Tabuenca test, it is better to use the fresh bud weight than the dry weight.

Water content in the buds can be an alternative method to estimate the end of the dormancy period.

\section{ACKNOWLEDGEMENTS, FINANCIAL SUPPORT AND FULL DISCLOSURE}

The authors express their acknowledgment to CAPES/ Embrapa for providing a scholarship to the first author and the resources for carrying out this work, to Gilberto Kuhn for helping with the sampling, to MSc Everton Pederzolli for the help with the graphics format and the Statistic department of the Federal University of Pelotas for the orientation with the statistics analysis. The authors have no conflicts of interest regarding the manuscript.

\section{REFERENCES}

Aguilera F, Ruiz L, Fornaciari M, Romano B, Galán C, Oteros J, Dhiab AB, Msallem M \& Orlandi F (2014) Heat accumulation period in the Mediterranean region: phenological response of the olive in different climate areas (Spain, Italy and Tunisia). International Journal of Biometeorology, 58:867-876.

Andreini L, Cortázar-Atauri IG, Chuine I, Viti R, Bartolini S, Ruiz D, Campoy JA, Legave JM, Audergon JM \& Bertuzzi P (2014) Understanding dormancy release in apricot flower buds (Prunus armeniaca L.) using several process-based phenological models. Agricultural and Forest Meteorology, 184:210-219.

Bonhomme M, Rageau R, Richard JP \& Gendraud M (1997) Dormancy of peach floral buds: biological and tentative biochemical approaches. Acta Horticulturae, 441:167-174.

Carvalho RIN, Biasi LA, Zanette F, Santos JM \& Pereira GP (2010) Estádios de brotação de gemas de fruteiras de clima temperado para o teste biológico de avaliação de dormência. Revista Acadêmica, Ciências Agrárias e Ambiental, 8:93-100.

Champagnat P (1973) Quelques aspects dês dormance chez lês végétaux. Bulletin Groupe Etude Rythmes Biologie, 4:47-59.

Chavarria G, Raseira MCB \& Zanandrea A (2000) Chilling requirement in peach. In: Prunus Breeders Meeting, Pelotas. Summaries, Embrapa. p.78-80.

Citadin I, Raseira MCB, Herter FG \& Silva JB (2001) Heat requirement for blooming and leafing in peach. HortScience, 36:305-307.

Dennis FG (2003) Problems in standardizing methods for evaluating the chilling requirements for the breaking of dormancy in buds of woody plants. HortScience, 38:347-350.

Donadio LC (2007) Dicionário das frutas. Jaboticabal, UNESP. 300p.

Erez A \& Lavee S (1971) The effect of climatic conditions on dormancy development of peach buds. I - Temperature. Journal of the American Society for Horticultural Science, 96:711-714.

Erez A (2000) Bud dormancy; phenomenon, problems and solutions in the tropics and subtropics. In: Erez A (Ed.) Temperate Fruit Crops in Warm Climates. Netherlands, Kluwer Academic Publishers. p.17-48.

Simões F, Hawerroth FJ, Yamamoto RR \& Herter FG (2014) Water content and carbohydrate dynamics of pear trees during dormancy in southern Brazil. Acta Horticulturae, 1058:305312 .

Fishman S, Erez A \& Couvillon GA (1987) The temperature dependence of dormancy breaking in plants: mathematical analysis of a two-step model involving a cooperative transition. Journal of Theoretical Biology, 124:473-483.

Franzon RC \& Raseira MCB (2014) Origem e história do pessegueiro. In: Raseira MCB, Pereira JFM \& Carvalho FLC (Eds.) Pessegueiro. Brasília, Embrapa. p.19-23. 
Gilreath PR \& Buchanan DW (1981) Rest prediction model for low-chilling 'Sungold' nectarine. Journal of the American Society for Horticultural Science, 106:426-429.

Gonçalves BHL (2014) Teores de carboidratos em pessegueiro cultivados em clima subtropical. Dissertação de Mestrado. Universidade Estadual Paulista, Faculdade de Ciências Agronômicas, Botucatu. 70p.

Hauagge R \& Cummins JN (1991) Phenotypic variation of length of bud dormancy in apple cultivars and related Malus species. Journal of the American Society for Horticultural Science, 116:100-106

Hawerroth FJ, Herter FG, Petri JL, Leite GB \& Pereira JFM (2010) Dormência em frutíferas de clima temperado (Revisão bibliográfica). Pelotas, Embrapa Clima Temperado. 56p. (Documentos, 310)

Herter FG, Machado LB, Oliveira MF \& Silva JB (2001) Efeito do frio na brotação de gemas de pereira (Pyrus communis L.) cv. Carrick, em Pelotas, RS. Revista Brasileira de Fruticultura, 23:261-264.

IPCC - Intergovernmental Panel on Climate Change (2013) Climate change 2013: The physical science basis. Available at: <https:/ /www.ipcc.ch/site/assets/uploads/2018/03/WG1AR5_SummaryVolume_FINAL.pdf $>$. Accessed on: April $20^{\text {th }}, 2019$.

Legave JM, Baculat B \& Brisson N (2010) Assessment of chilling requirements of apricot floral buds: comparison of three contrasting chilling models under mediterranean condition. Acta Horticulturae, 872:41-50.

Leite GB, Bonhomme M, Putti GL, Petri JL \& Rageau R (2006) Physiological and biochemical evolution of peach leaf buds during dormancy course under two contrasted temperature patterns. International Journal of Horticultural Science, 12:15-19.

Malagi G, Sachet MR, Citadin I, Herter FG, Bonhomme M, Regnard JL \& Legave JM (2015) The comparison of dormancy dynamics in apple trees grown under temperate and mild winter climates imposes a renewal of classical approaches. Trees, 29:13651380

Marafon AC, Herter FG \& Hawerroth FJ (2011) Umidade ponderal em tecidos de pereira durante o período de dormência sob condições de inverno ameno. Pesquisa Agropecuária Brasileira, 46:1006-1012.

Marodin GAB, Francisconi AHD \& Gallois ESP (1992) Efeito de produtos químicos na quebra de dormência e produção de pereira (Pyrus communis L.) cv. Packham's Triumph. Revista Brasileira de Fruticultura, 14:155-160.

Milech CG, Dini M, Scariotto S, Santos J, Herter FG \& Raseira MCB (2018a) Chilling requirement of ten peach cultivars estimated by different models. Journal of Experimental Agriculture International, 20:01-09.
Milech CG, Scariotto S, Dini M, Herter FG \& Raseira MCB (2018b) Models to estimate chilling accumulation under subtropical climatic conditions in Brazil. Revista Brasileira de Climatologia, 23:106-115.

Ou SK \& Chen CL (2000) Estimation of chilling requirement and development of low-chill model for local peach trees in Taiwan. Journal of the Chinese Society for Horticultural Science, 46:337350 .

Pouget R (1963) Recherches physiologiques sur le repos végétatif de la vigne (Vitis vinifera L.): la dormance des bourgeons des bourgeons et le mécanisme de sa disparition. Annuel Amélioration Plantes, 13:1-247.

Putti GL (2001) Estudo das necessidades de frio e calor para a brotação de cultivares de macieira (Malus domestica Borck.). Dissertação de Mestrado. Universidade Federal de Pelotas, Pelotas. 61p.

Richardson EA, Seeley SD \& Walker DR (1974) A model for estimating the completion of rest for 'Redhaven' and 'Elberta' peach trees. HortScience, 1:331-332.

Sachet MR (2013) Análises biológicas e bioquímicas na dinâmica da dormência de macieiras em Palmas - PR. Dissertação de Mestrado. Universidade Tecnológica Federal do Paraná, Pato Branco. 66p.

Tabuenca MC (1964) Necesidades de frío invernal de variedades de albaricoqueeero, melocotonero y peral. Estación Experimental de Aula Dei, 7:113-132.

Tabuenca MC (1967) Necesidades de frío invernal de variedades de ciruelo. Estación Experimental de Aula Dei, 8:383-391.

Walthall CL, Hatfield J, Backlund P, Lengnick L, Marshall E, Walsh M, Adkins S, Aillery M, Ainsworth EA, Ammann C, Anderson CJ, Bartomeus I, Baumgard LH, Booker F, Bradley B, Blumenthal CM, Bunce J, Burkey K, Dabney SM, Delgado JA, Dukes J, Funk A, Garrett K, Glenn M, Grantz DA, Goodrich D, Hu S, Izaurralde RC, Jones RAC, Kim SH, Leaky ADB, Lewers K, Mader TL, Mcclung A, Morgan J, Muth DJ, Nearing M, Oosterhuis DM, Ort D, Parmesan C, Pettigrew WT, Polley W, Rader R, Rice C, Rivington M, Rosskopf E, Salas WA, Sollenberger LE, Srygley R, Stöckle C, Takle ES, Timlin D, White JW, Winfree R, Wright-Morton L \& Ziska LH (2012) Climate change and agriculture in the United States: effects and adaptation. Washington, USDA. 186p. (Technical Bulletin, 1935)

Weinberger JH (1950) Chilling requirements of peach varieties. Proceedings of the American Society for Horticultural Science, $56: 122-128$. 